\title{
ITSBAT NIKAH DECISIONS ISSUED BY THE RELIGIOUS COURTS OF CLASS 1A BENGKULU ON THE SPOUSES WHOSE ABSENCE IN MARRIAGE DOCUMENTS ACCORDING TO ISLAMIC MARRIAGE LAW
}

By :

Kurniadi Agusta, Sirman Dahwal, Mohammad Darudin.

\begin{abstract}
In Bengkulu city, there is a marriage phenomenon done by the cultural law but not legally acknowledged in the data of ministry of religious office. Such a particular situation results in the absence of legal standing in terms of data. This being the case, spouses then ask for official marriage decisions or itsbat Nikah to the office of ministry of religious so that they would receive marriage letter. To answer the problems, the method used is empirical law research method. Data are obtained through observation and interviews to informant judges, clerks and seekers of justice who apply for marriage. Furthermore, it is analyzed by qualitative juridical with deductive and inductive method, thus it can be drawn a conclusion to answer from every existing problem. The results of this study indicate that: 1) many spouses do not have a marriage document since they avoid sin due to adultery, and feel not ready materially and socially, become pregnant out of marriage, and are overwhelmed with the assumption that whether having marriage documents or not will be the same, 2) the legal consequences of marriage without a marriage certificate are considered invalid because such a marriage is illegal under the law No. 1/1974 stating that the wife also has no right to the livelihood and inheritance of the husband if he dies and is not entitled to, (3) the religious courts of Bengkulu states that it is important to issue the-so-called itsbat Nikah or official documents to the spouses who have yet to legally declare their marriage as stated in the decree No.1/1974 for the betterment of the society.
\end{abstract}




\section{A. Introduction}

\section{Background of the Study}

In the Decision of the Supreme Court of the Republic of Indonesia No: KMA/032/SK/2006 on the Implementation of Book II Guidelines for the Implementation of Duties and Administration of Religious Courts, it is stated that: "itsbat Nikah is the endorsement of marriages which have been held on the basis of the Islamic law, but not officially recorded by religious office or VAT authorized. ${ }^{1}$ The ratification of marriages is regulated in the article 2 paragraph 5 of the decree No. 22/1946 jo article 49 point 22 explanation of the decree No. 7/1989 as amended by the law No. 3/2006 and the second amendment with law No. 50/2009 and article 7 paragraph 2, 3 and 4 in the compilation of Islamic Law. ${ }^{2}$

The marriage ceremony in the Religious Courts done by the applicants is used as the legal basis to register their marriage to the religious

\footnotetext{
1 Yusna Zaidah, Itsbat Nikah Dalam Perspektif Kompilasi Hukum Islam Hubungannya Dengan Kewenangan Peradilan Agama, http://www.media.neliti.com.

${ }^{2}$ Direktorat Badan Peradilan Agama Mahkamah Agung RI, Buku II Pedoman Pelaksanaan Tugas dan Administrasi Peradilan Agama. Mahkamah Agung RI, Jakarta. hlm. 143.
}

office or KUA District Marriage Certificate Officer, then the subdistrict will issue a quotation book of the marriage certificate as authentic proof that a marriage has been recorded. Further, the marriage certificate quotes will be employed to take care of the birth certificate of the child at the office of civil registry in which it is accompanied by the attachment of the ceremony of itsbat Nikah by the religious courts.

The religious courts with itsbat Nikah have an enormous and important contribution in providing a sense of justice and certainty as well as legal protection for the people. Those who do not have a family card due to the absence of marriage book, after the determination of itsbat Nikah by the religious courts, will easily take care of family card and birth certificate of their children, thus it is no trouble to enter schools. Even prospective pilgrims who do not have a marriage book are greatly helped by Itsbat Nikah by the religious courts to take care of passports.

Recording marriage is one form of government or state intervention to protect and ensure the fulfillment of social rights of every citizen especially married couples and 
children born in the marriage. Itsbat

Nikah will also provide legal certainty

to the status of marital treasures.

Based on the background of the above problem, the researcher is interested to discuss this issue under the title

"ITSBAT NIKAH DECISIONS ISSUED BY THE RELIGIOUS COURTS OF CLASS 1A BENGKULU ON THE SPOUSES WHOSE ABSENCE IN MARRIAGE DOCUMENTS ACCORDING TO ISLAMIC MARRIAGE LAW".

\section{Identification of Problems}

The research questions in this study are formulated as follows:

1) Why do many married spouses do not have legal marriage documents?

2) What are the legal consequences for the marriage that has no formal documents?

3) How is it seen from the persepctive of Islamic law to the process of itsbat Nikah issued by the Religious Court of Class IA Bengkulu against married couples who do not have a marriage certificate?
B. Methods of the Study

\section{Type of the Study}

The study employs empirical juridical research method, a legal research method that serves to see the law in the real sense and examines how the law works in the community. ${ }^{3}$

\section{Deciding the Informants}

The selected informants are in the following.

a. The informants group dealing with the case of itsbat Nikah directly namely 3 (three) Judges of Religious Courts Class IA Bengkulu and 1 (one) Class Registrar Court of IA Bengkulu.

b. The informants group consisting citizens applying itsbat Nikah at the religious court of Bengkulu.

\section{Data Collection Technique}

a. Observing

In this research, the researcher observed the implementation of the trial directly, for a certain period, to record the daily activities of the religious courts of class IA

${ }^{3}$ Bahder $\quad$ Johan
Nasution,
BetodePenelitian Ilmu Hukum,Mandar Maju,
Bandung, 2008. p.123.


Bengkulu both in patterns of interaction and communication patterns.

b. In-depth Interview

In this case the researchers conduct direct interviews in a guided free manner, ie interviews conducted to informants conducted freely based on a list of questions that have been prepared by researchers.

c. Secondary Data Collection.

In addition to the data collected through observation and direct and indepth interviews, secondary data collection is also done by reading, studying, recording and citing books literature and legislation are all related to the object of research.

\section{Data Processing}

In this research, the data are processed by editing, coding, and reconstructing the material (reconstructing) which rearranges the legal material regularly, sequentially and logically. Therefore, it is easily understood and interpreted. The last step is systematic material of law that is putting the material of law according to systematic framework of discussion based on the order of the problem.

\section{Results and Discussion}

1. The Married Spouses whose Absence in Marriage Documents

Realizing the importance of the legality of such a marriage, there arose the desire of the people to register and legalize their marriage. This can be proven by itsbat Nikah case in the religious court of class IA Bengkulu. In 2015, the Religious Courts of Class IA Bengkulu have received and examined marriage cases as many as 6 cases and in 2016 and as many as 27 cases as well in 2017 as many as 57 cases, according to the following table.

By studying the cases, the researcher then can analyze some problems that encourage married couples do not have a marriage certificate that can be summarized as follows:

a) Marriage not recorded is done under the pretext of avoiding the $\sin$ of adultery. These concerns are experienced by Ani and Yono student couples. The relationship is getting closer day by day, raising concerns about the occurrence of acts that violate sharia.

b) Marriage is not recorded because the couples feel not 
ready materially and socially. In addition to worrying about adultery, they are still in college and have yet to prepare if the burden of household comes.

c) Pregnant out of marriage. As a result of the promiscuity between men and women, who no longer heed the norms and rules of religion is the occurrence of pregnant out of wedlock. Pregnancy that occurred outside the marriage, is a disgrace for families who will invite scorn from the community. From there the parents marry under the hands of their children with men who impregnate them on the grounds of rescuing the family's good name and without involving the VAT officer, but only done by mualim (there is a marriage term by kiyai) without registering.

d) The presumption that marriage recorded and not recorded the same. Whereas it has been described in the Marriage Law as follows: "Every marriage is recorded according to the rules applicable (Article 2 paragraph
(1) of Law number 1 year 1974).

e) The presumption that marriage in KUA is expensive, so the couple is married under the hands that they consider legitimate in the eyes of religion and also does not require a large cost. Whereas in the PP 48 of 2014 about the cost of marriage registration or reconciliation fees in KUA on weekdays, free of charge or free. Likewise for those who cannot afford economically and the people affected by natural disasters are charged zero rupiah tariff, as long as they attach the requirement of certificate of incapacity (SKTM) from village or village head. Meanwhile, if married outside KUA and outside working hours, charged IDR. 600 thousand paid through the bank.

\section{Legal Consequences of Marriage} Who Have No Marriage Certificate

a. The consequences of marriage law that do not have marriage certificate in view of Law No.1 Year 1974. Legal consequences that will occur from marriages 
that do not have the deed of marriage are as follows.

1. To the Wife and Husband

Legally, the wife of marriage in the absence of a marriage certificate is considered invalid because their marriage is not valid according to Law Number 1 Year 1974. The wife is also not entitled to the livelihood and inheritance of the husband if he dies and vice versa and has no right on the properties in case of divorce. This is because legally their marriage is considered never happened.

\section{To the Kids}

The unlawful marriage under the law, has a negative impact on the status of the born kids. The kid is considered an illegitimate child, as described in the Article 42 of Law Number 1 Year 1974 stating that: "Legitimate child is a born child in or as a result of a legitimate marriage".

a. The legal consequences of marriages that did not have Marriage Certificate in terms of Islamic Law Compilation.

When viewed from the provisions of Islamic Law Compilation, then obtained the conclusion that the marriage without a marriage certificate is not valid, because it is not recorded as mentioned in Article 5 and Article 6 $K H I$, because the legal element of a marriage with the registration procedures was applied cumulatively.

This means that KHI basically holds the same view as Law No. 1 of 1974 concerning unregistered marriage. Regarding the legal consequences of registered marriage according to $K H I$ is basically the same as regulated in Law No. 1 of 1974.

b. The legal consequences of marriages that did not have Marriage Certificate in terms of Islamic Law.

Marriages that did not have a marriage certificate as long as the marriage of harmony and fulfill the conditions it can be said valid according to religion, but it is not lawful according to positive law in Indonesia. In anticipation of the adverse effects of unregistered marriage, particular the protection of the wife, then the MUI Fatwa recommends that unregistered marriage should be listed officially on the authorities. With the existence of this recording, then this marriage either in law or state law to be valid. And, this is important for the fulfillment of the rights of wives and 
children, especially about the distribution of the estate, the recognition of the child status and if there is a problem, the wife has a strong legal basis to sue her husband.

3. The legal view of the Islamic Marriage againts giving Itsbat Nikah by Class IA of Religious Court of Bengkulu toward husband and wife that did not have Marriage Certificate.

a. The mechanism of Filing Itsbat Nikah Case

1. Apply

The applicant who come to the Religious Courts to apply for request Itsbat petition or marriage approval, firstly facing to the table 1 or the Young Clerk Request to obtained information about the procedure of making the Itsbat / marriage application letter. The Itsbat / marriage application letter must contain name, age, residence and identity of other applicants, the reasons which form the basis of diitsbatkan / the marriage legalization (posita) and a request that the marriage declared valid by the Religious Courts (petition).

\section{Registration}

The applicant with the application letter of Itsbat or the marriage legalization was facing the desk clerk I, and the desk clerk I made a Letter of Authorization to Pay (SKUM). The application letter of Itsbat or new marriage approval will be registered on the list of Religious Court case, if the applicant has paid the down payment fee. The down payment fee estimated by the chairman of the Court, the fee was used for recording fees, administration, by a court order $(A P P)$, the call and the stamp price to be used. The down payment fee that will be calculated later after the case ended.

\section{Callings}

Each time a trial is held, the applicant shall be summoned to the hearing by the substitute bribe on the orders of judge's chairman. The ssummons must be delivered directly to the residence and the person of the applicant, if it cannot be delivered directly, then the summons submitted to the village head or subdistrict head or local pembakal, and it should be done properly and has been received by the parties concerned not later than 
three days before the trial is opened.

4. Trial

The trial of Itsbat or the marriage legalization conducted by the judge / judges, no later than 30 days after receipt of the petition application file. In the trial proceedings, the judges directly read the petition of the applicant, if the petition was retained by the applicant, it followed by proof, conclusions and determination readings. The examination of the Itsbat Nikah application case was conducted by judge panel with a trial opened and open to the public.

\section{Completion}

After the Itsbat Nikah application was decided by the determination, within 14 days no appeal filed by the applicant, then determination has permanent legal force, therefore the final solution of the case was the desk clerk III issued a copy of the stipulation that must be accepted by the applicant.
a. The Legal Basis of Judge
Consideration
The considerations and legal basis used when granting of Itsbat Nikah case include:

1. The reason of Maslahah Mursalah means judge granted a Itsbat Nikah case based on the consideration of the family members benefit, and legal protection of the child interests who desperately need protected. For example, a child who wants to go to school does not have a birth certificate, because the birth certificate is a requirement for school. By granting the parents request, the marriage certificate will be issued so that the future interests of the child will be protected by law.

2. Because the unregistered marriage for some people of the local area is a habit, and a judge should not refuse the case delegated to him that is required to explore the local customary law, the judge is not funnel of the Law, in this case the judges based on the Kaedah Fiqh Al'adah Al Muhakamah ( custom is a law) and dar'ul mafasyid maqomu jalbul masholeh. Although the unregistered marriage done by capable person. 
3. In Islamic Law Compilation (KHI) has been described in Article 5 paragraph (3e), "Marriage conducted by those who do not have marital obstacles according to Law No. 1 of 1974". This article also used by Judges of Bengkulu Religion Court, as the basis for granting Marriage Itsbat. Because in the view of the judges, the article is a form of anticipation (cover) againts the facts that it could happened for unregistered married couples who married not because of non-compliance with the Law. As long as the marriage is valid (in accordance with its terms) according to Islamic Syariah it was considers to have no impediment to isbating marriage.

Besides, the basis judge's considerations in giving decision or determination of Itsbat Nikah at the Religious Court of Bengkulu are:

a. Legal standing (legal standing) of the applicant to litigate Itsbat Nikah in a religious court, whether the applicant is a party that has an interest in the legal standing under the provisions of Article 7 paragraph (4) KHI

b. Posita (incidence facts and legal facts)

c. Statements of witnesses and evidence in the trial

d. The reasons for submit Marriage Itsbat.

b. The Itsbat Nikah Terms of Islamic Law

The depth of marriage meaning in Islamic law brings consequences for Muslims to obey, respect, honor and preserve the marriage institution, especially by the husband and wife. Conversely, if distorting and polluting by actions that are not in harmony with the nature of marriage is futile and will lead to damage in the household, especially for the future of the children were born.

As for the Islamic law, married couples who do not register marriages at state registration offices, basically, the function of marriage recording at civil registration offices is for 
someone to have evidence (bayyinah) to prove that he/she really has married with others. Therefore, one of the proofs that are considered valid as evidence syar'iy (bayyinah syar'iyyah) is an official document issued by the state.

B. Closing SPOUSES WHOSE ABSENCE IN MARRIAGE DOCUMENTS

\section{Conclusion}

a. Many spouses whose absence in marriage certificate, under the pretext that:

1) Avoiding the sin of adultery.

The unregistered marriage is considered as a way out that can justify the fluctuation of love as well as eliminate the fear of adultery.

2) The couples feel unprepared materially and socially, because they have not had the preparation if they shall be burdened by household problems.

3) Unwed pregnancy/ Pregrant out of wedlock.
4) The presumption that registered and unregistered marriage is same.

5) The presumption that registered marriage needs fairly expensive cost.

b. The legal consequences for marriage that do not have a marriage certificate

1) Judging from the Law No. 1 of 1974

The marriage without a marriage certificate is considered invalid, because their marriage was not authorized by Law No. 1 of 1974, the wife is not entitled to the livelihood and inheritance of her husband if he dies and vice versa, and is not entitled to the Gono-gini property in case of divorce.

2) Judging from the Islamic Law Compilation

The marriage without a marriage certificate is invalid because it does not do the recording as mentioned in Article 5 and Article $6 \mathrm{KHI}$, because the legal element of a marriage with the elements of registration procedures applied cumulatively. This 
means basically $K H I$

embraces the same view with

Law No. 1 of 1974 concerning unregistered marriage. Regarding the legal consequences of registered marriage according to $K H I$ is basically the same as regulated in Law No. 1 of 1974

3) Judging from the Islamic law According to Islamic law, if a marriage has been carried out and has met the condition adn requirement of marriage, then the marriage is legally valid according to Islamic Law. The marriage without certificate is legal since it has fulfiled the condition and requirement of marriage, but will be haram because there are victims of wife and child .

c. The legal view of Islamic marriage on the giving of Itsbat Nikah by Religious Court of Bengkulu Class IA against married couples who do not have a marriage certificate. The Law No. 1 of 1974 is solely for the benefit of the people, besides that the panel judges also have the legal considerations which are strong enough to grant the case.

\section{Suggestion}

a. For the sake of legal certainty, it should be done immediate revision on Law No. 1 of 1974 particularly on the status of marriage registration as a condition for the marriage validity, and there must be firmness of unregistered marriage and the sanctions on the protection of women / wives and their descendants.

b. For the sake of the future, for the Indonesian Muslims in implementing the wedding must comply with the provisions of Islamic marriage law and implementing the legislation of the Republic of Indonesia, but to the couples who have not registered their marriage or who have been married by unregistered marriage need to apply the Itsbat Nikah in Religious Court. And for couples who have just married by unregistered marriage and have no children, then the marriage legalization by repeating the marriage or 
recorded in the local Religious

Affairs Office therefore their marriage was legally valid. And also for teenagers and unmarried couples candidate, or will get married and parents need counseling in order to build awareness of the law. By providing socialization to the society about consequences and disadvantages of Siri marriage. The goal is that unregistered marriage does not occur in society continuously.

c. Itsbat Nikah is one of the solutions for marriages that did not have a marriage certificate or undocumented, it should be done at a relatively accessible fee/cost by the community. Because if the cost is too high will only lead to citizens unwilling to deal with the Court. Besides, the judge should be cautious in determining the validity of the marriage.

\section{REFERENCES}

$\begin{array}{cr}\text { Bahder } \quad \text { Johan } & \text { Nasution, } \\ \text { MetodePenelitian } & \text { Ilmu } \\ \text { Hukum, Mandar Maju, Bandung, } \\ \text { 2008. }\end{array}$

Direktorat Badan Peradilan Agama Mahkamah Agung RI, Buku II Pedoman Pelaksanaan Tugas dan Administrasi Peradilan Agama. Mahkamah Agung RI, Jakarta.

Yusna Zaidah, Itsbat Nikah Dalam Perspektif Kompilasi Hukum Islam Hubungannya Dengan Kewenangan Peradilan Agama, http://www.media.neliti.com. 